\title{
SPESIFIKASI, CARA OPERASI, DAN HASIL TANGKAPAN ALAT TANGKAP BLAD (BEACH BARRIER TRAP) DI PERAIRAN ESTUARI YANG BERMUARA DI SELAT BANGKA, SUMATERA SELATAN
}

\author{
Rupawan'), Abdul Karim Gaffar'), dan Khoirul Fatah') \\ 1)Peneliti pada Balai Riset Perikanan Perairan Umum, Mariana-Palembang \\ Teregristrasi I tanggal: 9 Agustus 2007; Diterima setelah perbaikan tanggal: 7 Januari 2008; \\ Disetujui terbit tanggal: 10 Januari 2008
}

\begin{abstract}
ABSTRAK
Perairan estuaria merupakan wilayah pertemuan air tawar dari sungai dengan air laut, mempunyai karakteristik habitat yang khas dan dinamis, keanekaragaman hayati tinggi, aktivitas perikanan tangkap dengan bermacam jenis alat tangkap cukup berkembang. Penelitian untuk mengetahui spesifikasi, cara operasi, dan hasil tangkapan alat tangkap blad dilakukan dengan metode survei pada tahun 2006 di perairan estuari yang bermuara di Selat Bangka, Sumatera Selatan. Hasil penelitian menunjukkan bahwa alat tangkap blad dibuat dari bahan jaring mesh size $4 \mathrm{~mm}$, ukuran panjang 100 sampai dengan $400 \mathrm{~m}$, lebar 2,0 sampai dengan 3,0 m. Alat tangkap pasif, dipasang memanjang garis pantai pinggiran sungai, menjebak ikan yang bermigrasi secara lateral saat air pasang. Dapat dioperasikan 14 sampai dengan 18 hari per bulan sepanjang tahun, dominan musim kemarau. Hasil tangkapan terdiri atas 54 jenis ikan dan 7 jenis udang, komposisi bobot ikan $73 \%$ dan udang $27 \%$. Nilai indek keragaman jenis 1,95 sampai dengan 2,87 (tingkat sedang). Hasil tangkapan per unit upaya (catch per unit of effort) 2,31 sampai dengan 8,75 kg per $100 \mathrm{~m}$ jaring blad per trip operasi.
\end{abstract}

KATAKUNCl: $\quad$ blad, estuari, Selat Bangka

\section{PENDAHULUAN}

Sumber daya perikanan perairan umum di Sumatera Selatan berperan besar sebagai tempat usaha perikanan tangkap, sumber pendapatan rumah tangga nelayan, sumber protein hewani dan pendapatan asli daerah. Pemanfaatan sumber daya perikanan perairan umum atau izin penangkapan (fishing access) di Sumatera Selatan didapatkan melalui lelang lebak lebung yang dilakukan setiap tahun oleh Pemerintah Kabupaten. Sumber daya perikanan perairan umum tersebut perlu dikelola dengan baik agar kontribusi dan pemanfaatan dapat dipertahankan bahkan ditingkatkan (Gaffar, 1999).

Agueron \& Lockwood (1986) mengatakan bahwa walaupun sumber daya perikanan sebagai suatu sumber daya alam yang dapat pulih, namun produktivitas dapat menurun bahkan jenis ikan tertentu dapat punah apabila tidak dikelola atau pengelolaan kurang baik.

Perairan umum estuaria merupakan bagian dari daerah aliran sungai yang berada di bagian hilir. Selain menjadi penangkap hara juga sebagai penangkap polutan, karakteristik habitat sangat dinamis dan khas. Secara ekologi, perairan estuaria mempunyai ciri khas ada pengaruh pasang surut air laut dengan fluktuasi salinitas, kekeruhan, arus air, dan keragaman jenis ikan baik ikan air tawar maupun ikan yang berasal dari laut. Di Sumatera Selatan khususnya di Kabupaten Banyuasin bermuara 4 sungai ke Selat
Bangka yaitu Sungai Upang, Sungai Musi, Sungai Banyuasin, dan Sungai Sembilang, membentuk ekosistem estuaria karena berkoneksi dengan perairan laut Selat Bangka. Perairan estuaria di Kabupaten Banyuasin merupakan sentra perikanan tangkap di Sumatera Selatan dengan menggunakan berbagai alat tangkap baik yang digunakan di perairan tawar atau di perairan laut. Wardoyo et al. (2001) mengatakan bahwa $90 \%$ penduduk yang tinggal di perairan estuaria Banyuasin bekerja sebagai nelayan atau pengolah produk perikanan.

Jenis alat tangkap yang digunakan pada suatu daerah penangkapan pada umumnya menyesuaikan dengan karakteristik habitat, dinamika fisika kimia air, dan kebiasaan ikan (fish behavour). Sedangkan produktivitas usaha perikanan tangkap di perairan umum antara lain ditentukan oleh jenis alat tangkap, keterampilan, dan pengalaman nelayan, serta kelimpahan stok ikan.

Penelitian ini bertujuan untuk mendapatkan data dan informasi tentang spesifikasi, cara operasi, dan hasil tangkapan alat tangkap blad di perairan estuaria sungai yang bermuara di Selat Bangka, Sumatera Selatan sebagai bahan evaluasi dan kebijakan pengaturan penangkapan ikan.

\section{BAHAN DAN METODE}

Penelitian untuk mengetahui spesifikasi, cara operasi, dan hasil tangkapan alat tangkap blad sebagai 
bahan kebijakan penangkapan telah dilakukan dengan metode survei di perairan estuaria Sungai Upang, Sungai Musi, Sungai Banyuasin, dan Sungai
Sembilang Kabupaten Banyuasin, Sumatera Selatan (Gambar 1) pada tahun 2006.

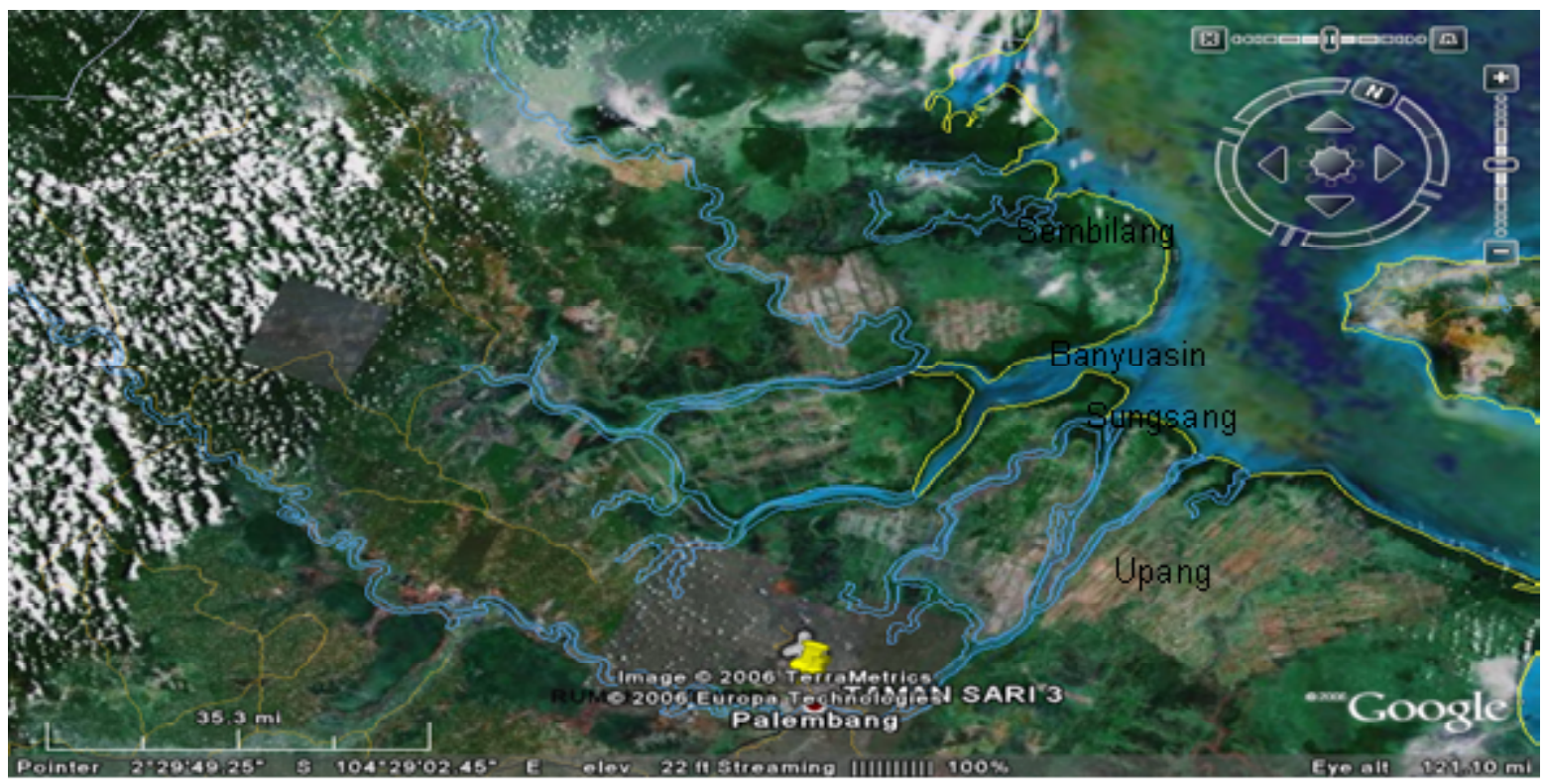

Gambar 1. Peta perairan estuaria Sungai Upang, Sungai Musi, Sungai Banyuasin, dan Sungai Sembilang Kabupaten Banyuasin, Sumatera Selatan, tahun 2006.

Pengumpulan data dan informasi dilakukan dengan cara pengamatan dan wawancara pada nelayan blad masing-masing 3 orang pada setiap sungai yang ditentukan secara acak yaitu nelayan yang sedang melakukan kegiatan penangkapan. Pengamatan spesifikasi alat meliputi bahan, ukuran, wawancara tentang ketahanan alat, musim dan hari kerja. Pengamatan cara operasi dilakukan mulai tahap persiapan, pemasangan alat sampai dengan panen hasil. Pengamatan hasil tangkapan meliputi komposisi jenis dan bobot, indek keragaman, dan catch per unit of effort. Spesifikasi alat dan cara operasi dijelaskan dengan bantuan gambar dan sketsa. Total hasil tangkapan dikelompokkan berdasarkan pada jenis, masing-masing kelompok jenis dihitung jumlah (ekor) dan ditimbang bobot. Contoh ikan dan udang diawetkan dalam larutan formalin 10\% untuk diidentifikasi di laboratorium Balai Riset Perikanan Perairan Umum. Identifikasi dilakukan dengan cara membuat deskripsi dan selanjutnya dibandingkan dengan kunci determinasi Kottelat et al. (1993); Weber M. \& De Beufort (1916).

Indeks keanekaragaman ikan ditentukan berdasarkan pada indeks Shannon (Bengen, 2000).

$$
H^{\prime}=-\sum\left[\frac{n_{i}}{N} \ln \frac{n_{i}}{N}\right]=-\sum\left(p_{i} \ln p_{i}\right)
$$

di mana:

$H^{\prime}=$ indeks keanekaragaman

$$
\begin{aligned}
& n_{i}=\text { jumlah individu masing-masing spesies } \\
& N=\text { jumlah individu keseluruhan, } \mathrm{P} i=\frac{\mathrm{ni}}{N}
\end{aligned}
$$

Kriteria menurut Wil et al. (1988) dalam Bengan (2000):

$H^{\prime}>3=$ keanekaragaman jenis tinggi

$1<H^{\prime}<3=$ keanekaragaman jenis sedang

$H^{\prime}<1=$ keanekaragaman jenis rendah

Catch per unit effort, dianalisis dengan menggunakan rumus:

CPUE $=\frac{Y}{f}$

di mana:

$Y=$ hasil tangkapan $(\mathrm{kg})$

$f \quad=$ upaya penangkapan (effort)

\section{HASIL DAN BAHASAN}

\section{Spesifkasi Alat}

Spesifikasi alat tangkap blad pada 4 lokasi pengamatan tidak berbeda, yaitu dibuat dari bahan jaring (waring) mesh size 4,0 $\mathrm{mm}$, ukuran panjang 100 sampai dengan $400 \mathrm{~m}$ lebar 2,0 sampai dengan 3,0 $\mathrm{m}$, sepanjang bagian bawah dan atas jaring dilengkapi tali ris benang nilon polyfilamen diamater 
3,0 sampai dengan $5,0 \mathrm{~mm}$. Agar jaring dapat terbentang vertikal saat operasional, setiap jarak 4 sampai dengan $5 \mathrm{~m}$ dipasang tiang kayu atau bambu diamater 10 sampai dengan $15 \mathrm{~cm}$. Ketahanan alat dapat mencapai 2 tahun.

\section{Cara Operasi}

Alat tangkap blad bersifat pasif, dioperasikan dengan memanfaatkan dinamika air pasang dan surut. Sehubungan dengan itu nelayan alat tangkap blad punya pengetahuan yang baik tentang dinamika ketinggian air saat pasang puncak dan surut terendah, karena sangat berkaitan dengan di mana posisi jaring blad dipasang dan pada saat kapan jaring blad ditutup atau diangkat. Cara operasi alat tangkap blad pada 4 lokasi pengamatan tidak berbeda, yaitu menangkap ikan dengan cara menjebak atau mengurung ikan bermigrasi secara lateral saat air pasang. Jaring blad dipasang pada pantai yang landai saat air surut yaitu pada posisi garis pantai permukaan air surut terendah (Gambar 2), hal ini bertujuan agar ikan yang terjebak dalam lahan blad mudah dipanen saat air surut terendah.

Tali ris jaring yang bersatu dengan jaring blad bagian bawah dibenamkan dalam lumpur lebih kurang $20 \mathrm{~cm}$, bila dasar perairan tidak berlumpur setiap jarak $1 \mathrm{~m}$ dibantu dengan patok kayu kecil bercabang. Seluruh jaring blad lebar 2,0 sampai dengan 3,0 m, panjang 100 sampai dengan $400 \mathrm{~m}$ digulung atau ditumpuk arah memanjang di dasar perairan sesuai

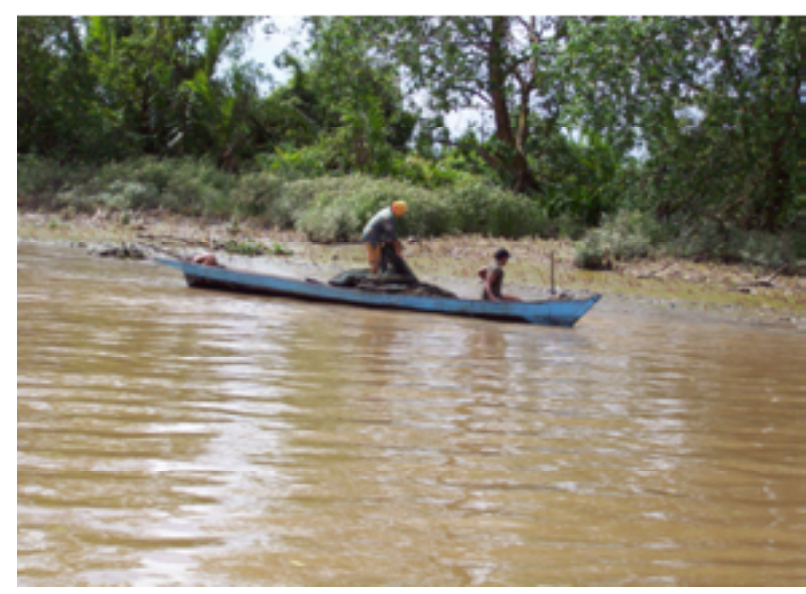

Gambar 2. Jaring blad dipasang pada pantai yang landai saat air surut. arah barisan tiang atau patok kayu.

Air pasang, air mengenangi lahan pantai yang telah disiapkan jaring blad, ikan bermigrasi secara lateral ke pinggir sungai untuk berlindung dan mencari makan. Saat pasang puncak (permukaan air pasang tertinggi), tali ris bagian atas jaring diangkat dan disangkutkan pada ujung tiang kayu, jaring blad terbentang menbentuk pagar, menghadang, menjebak, dan mengurung ikan yang akan ke luar dari lahan blad pada saat air surut (Gambar 3 dan 4).

Kedua ujung unit jaring blad dipasang mengarah daratan yang lebih tinggi. Alat tangkap blad dipasang di pantai yang landai dengan jarak antara 7 sampai dengan $10 \mathrm{~m}$ dari daratan tepian sungai, sehingga pada ketinggian air tertentu didapat lahan jebakan rata-rata 900 sampai dengan $3.600 \mathrm{~m}^{2}$. Alat tangkap blad dioperasikan pada saat pasang purmana atau pasang tunggal yaitu 14 sampai dengan 18 hari per bulan, sepanjang tahun, dominan musim kemarau. Dibanding jenis alat tangkap yang lain berdasarkan pada jumlah dan sebaran, alat tangkap blad dominan ke-2 setelah alat tangkap tuguk (filtering divice). Lokasi pemasangan blad setiap hari operasi berpindah atau bergeser ke tempat lain sampai dengan beberapa waktu kembali lagi. Operasional alat dikerjakan oleh 2 sampai dengan 3 orang, tahap persiapan memerlukan waktu kerja \pm 30 menit, pemasangan alat \pm 15 menit, dan penen \pm 40 menit per $100 \mathrm{~m}$ jaring blad. Total waktu yang diperlukan 1 trip operasi 85 menit per $100 \mathrm{~m}$ jaring blad.

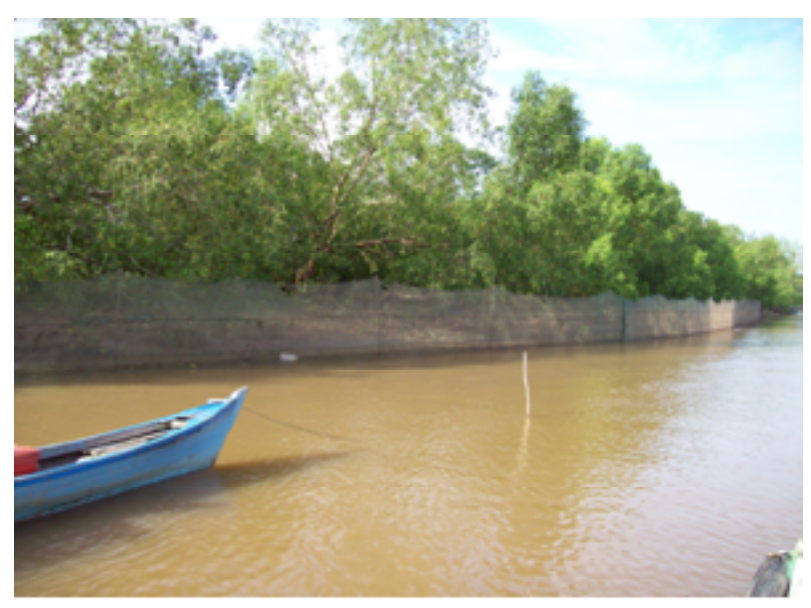

Gambar 3. Lahan blad pada saat air surut. 

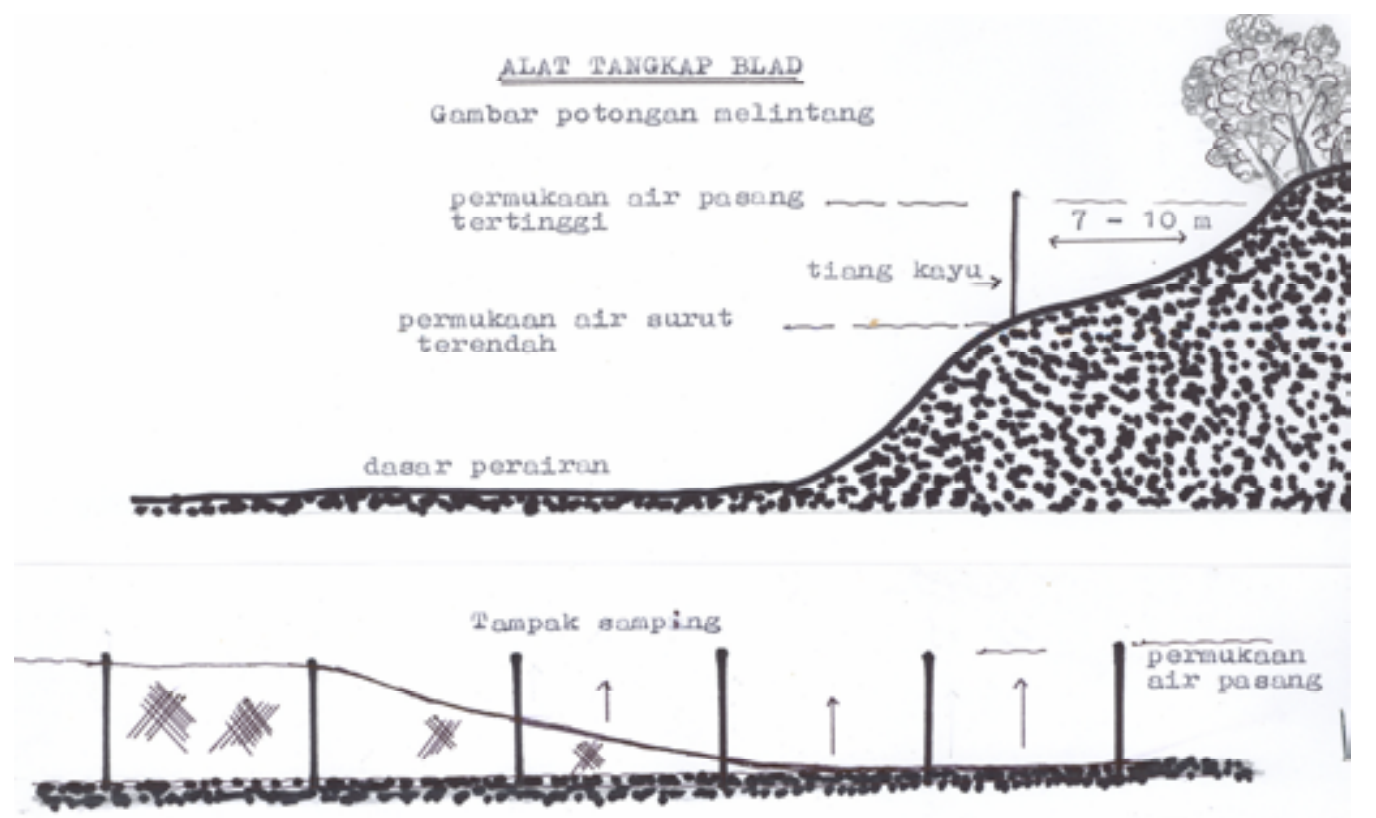

Gambar 4. Alat tangkap blad.

\section{Hasil Tangkapan}

Rata-rata jumlah dan komposisi jenis hasil tangkapan 3 orang nelayan pada masing-masing lokasi pengamatan yaitu perairan estuaria Sungai Upang, Sungai Musi, Sungai Banyuasin, dan Sungai Sembilang seperti disajikan pada Tabel 1.

Tabel 1. Komposisi jenis dan rata-rata jumlah (ekor) dan bobot (g) hasil tangkapan alat tangkap blad pada masing-masing lokasi pengamatan

\begin{tabular}{|c|c|c|c|c|c|}
\hline \multirow[b]{2}{*}{ No. } & \multirow[b]{2}{*}{ Jenis ikan } & \multicolumn{4}{|c|}{ Lokasi penelitian atau hasil tangkapan ekor (g) } \\
\hline & & $\begin{array}{l}\text { Sungai } \\
\text { Upang }\end{array}$ & Sungai Musi & $\begin{array}{c}\text { Sungai } \\
\text { Bamyuasin }\end{array}$ & $\begin{array}{c}\text { Sungai } \\
\text { Sembilang }\end{array}$ \\
\hline & Aro mato merah (Osteochilius melanopieura) & $21(775)$ & & & \\
\hline 2. & Baung (Wystus nemerus) & $1(340)$ & & & \\
\hline 3. & Baung munti (Bagroides melaptens) & $3(64)$ & & & \\
\hline 4. & Belanak (Liza melinoptera) & $19(760)$ & $10(400)$ & $2(80)$ & $81(3.240)$ \\
\hline 5. & Belumbungan (Otoithus rubber) & $1(76)$ & $5(380)$ & $105(1.141)$ & $21(1.598)$ \\
\hline 6. & Belut tulang (Cryptoptens apagon) & $1(50)$ & & & \\
\hline 7. & Bilis (Cupeichthys sp) & $125(245)$ & & & \\
\hline 8. & Blambangan (Lutjanus fuscescens) & & & & $8(49)$ \\
\hline 9. & Buntal (Tetraodon poiembangensis) & & $2(66)$ & & \\
\hline 10. & Cawang (Polmemus indicus show) & & $2(152)$ & & \\
\hline 11. & Cumi (Loligo sp.) & & & & $3(339)$ \\
\hline 12. & Dukang (Arius sagor) & & $7(1.855)$ & & $14(3.710)$ \\
\hline 13. & Duri (Arius biotetocephaius) & $5(400)$ & $34(2.720)$ & & \\
\hline 14. & Elang (Coisquadrias ciatus) & $13(1.245)$ & $11(1.045$ & & \\
\hline 15. & Gabus (channa striata) & $21(2.410)$ & & & \\
\hline 16. & Grot (Lutjanus russeiii) & & & & $8(1.545)$ \\
\hline 17. & Gulamo (Otolithoides pama) & $23(1.759)$ & $3(230)$ & & \\
\hline 18. & Gulamo keken (Juhnius trachycephaius) & $13(523)$ & $2(81)$ & & \\
\hline 19. & Janggut (Folynemus iongipectoralis) & $32(220)$ & & & \\
\hline 20. & Juaro (Pangasius polyuronodon) & $56(2.268$ & & & \\
\hline & Julung-julung (Zenarchopterus buffonis) & $181(90)$ & $20(10)$ & & \\
\hline 22. & Kakap (Lates Calcanifen) & $5(1.283)$ & $5(128)$ & $11(2.822)$ & $20(5.132)$ \\
\hline
\end{tabular}


Tabel 1

(Lanjutan)

\begin{tabular}{|c|c|c|c|c|c|}
\hline 23. & Kepiting (Scyla serrata) & & $3(10)$ & & $3(11)$ \\
\hline 24. & Kerapu (Epinephelus beekeri) & & & & 1( 33$)$ \\
\hline 25. & Kiper (Scatophagus argus) & $39(1.400)$ & $12(431)$ & $73(2.621)$ & $40(1.440)$ \\
\hline 26. & Lais bemban (Kryptopterus limpok) & $13(49)$ & & & \\
\hline 27. & Lais kaco (Kryptopterus cryptopterus) & $52(332)$ & & & \\
\hline 28. & Lais muncung (Kryptopterus micronema) & $7(38)$ & & & \\
\hline 29. & Lais tapa (Silurodes hexapterus) & $98(1.225)$ & & & \\
\hline 30. & Lampam (Burbodesschwanefeldii) & $1(35)$ & & & \\
\hline 31. & Lele (Clarias gatrocus) & $2(80)$ & & & \\
\hline 32. & Lepu (Leptosynanceia asteroblepa) & & $5(130)$ & $3(78)$ & $4(104)$ \\
\hline 33. & Lidah (Cynoglassus feldmanni) & $3(135)$ & $6(270)$ & $2(90)$ & $1(45)$ \\
\hline 34. & Lumajang (Cyclocheilichtys enoplos) & $8(141)$ & & & \\
\hline 35. & Lundu (Mystus wolffi) & $223(1.025)$ & $5(23)$ & $6(28)$ & \\
\hline 36. & Pari (Amphotistius imbricatus) & $1(73)$ & & & $3(219)$ \\
\hline 37. & Permato (llisha elongata) & & & & $14(670)$ \\
\hline 38. & Pirang (Setipinna taty) & & & & $5(32)$ \\
\hline 39. & Puntung hanyut(Balantiocheilos melanopterus) & $1(67)$ & & & \\
\hline 40. & Selontok dompok (Bostrychus sinensis) & $16(104)$ & & $4(26)$ & \\
\hline 41. & Selontok kuning (Glossogobius biocellatus) & $14(129)$ & $4(37)$ & $3(28)$ & \\
\hline 42. & Selontok muncung & $32(393)$ & $8(98)$ & $2(15)$ & \\
\hline 43. & Seluang (Rasbora borneensis) & $119(726)$ & & & \\
\hline 44. & Sembilang (Plotasus canius) & $4(100)$ & $16(1.600)$ & $11(1.100)$ & $18(1.800)$ \\
\hline 45. & Senangin (Eleutheronema tetradactylum) & $2(49)$ & $30(738)$ & & \\
\hline 46. & Sengarat (Belodontichthys dinema) & $2(150)$ & & & \\
\hline 47. & Sepatung (Pristolepis fasciata) & $2(180)$ & & & \\
\hline 48. & Sepengkah (Ambassis kopsii) & $254(1.122)$ & & & \\
\hline 49. & Siamis (Chela oxyqaster) & $6(24)$ & & & \\
\hline 50. & Sihitam (Labeo chrysophexadeon) & $4(221)$ & & & \\
\hline 51. & Sotong (Sepia sp.) & & & & $2(220)$ \\
\hline 52. & Sumpit (Toxotes Micropis) & $10(820)$ & $4(329)$ & $2(165)$ & \\
\hline 53. & Tapa (Wallago Leeri) & $1(12)$ & & & \\
\hline 54. & Tilan (Masteccembulus unicolor) & $6(690)$ & & & \\
\hline 55. & Udang buku (Macrobracium sp.) & $353(2.181)$ & $388(2.398)$ & & $39(241)$ \\
\hline 56. & Udang Burung (Penaeus merguiensis) & & $43(645)$ & $5(75)$ & $171(2.565)$ \\
\hline 57. & Udang cat (Parapenaeopsis sp.) & & & $5(50)$ & $12(117)$ \\
\hline 58. & Udang galah (Macrobracium rosenbegii) & $170(10.370)$ & $75(4.575)$ & $15(915)$ & $1(61)$ \\
\hline 59. & Udang peci (Penaeus sp.) & $2(15)$ & $203(1.481)$ & & \\
\hline 60. & Udang pepe (Metapenaeusnensis) & $69(135)$ & & & $130(253)$ \\
\hline & Udang serengkek & $80(280)$ & & & \\
\hline & Jumlah jenis (S) & 47 & 25 & 13 & 21 \\
\hline & Jumlah individu (N) & 2.115 & 903 & 249 & 599 \\
\hline & Jumlah bobot (g) & 35.000 & 19,835 & 9.230 & 23.300 \\
\hline & Catch per unit of effort & 8,75 & 4,95 & 2,30 & 5,80 \\
\hline & Indek keragaman $(\mathrm{H})$ & 2,87 & 1,95 & 1,67 & 2,17 \\
\hline
\end{tabular}

Tabel 1 menunjukan bahwa jumlah jenis hasil tangkapan 61 jenis, terdiri atas 54 jenis ikan dan 7 jenis udang. Komposisi jenis pada masing-masing lokasi pengamatan; perairan estuaria Sungai Upang (47 jenis) paling tinggi dibanding estuaria Sungai Musi (25 jenis), estuaria Banyuasin (13 jenis), dan estuaria Sungai Sembilang (21 jenis). Berdasarkan pada komposisi jumlah (ekor), hasil tangkapan di estuaria Sungai Upang dan Sungai Musi di didominasi udang buku (Macrobracium sp.), Sungai Banyuasin didominasi ikan blumbungan (Otolithus rubber), estuaria Sungai sembilang didominasi udang burung (Penaeus merguiensis) (Gambar 5 dan 6). 


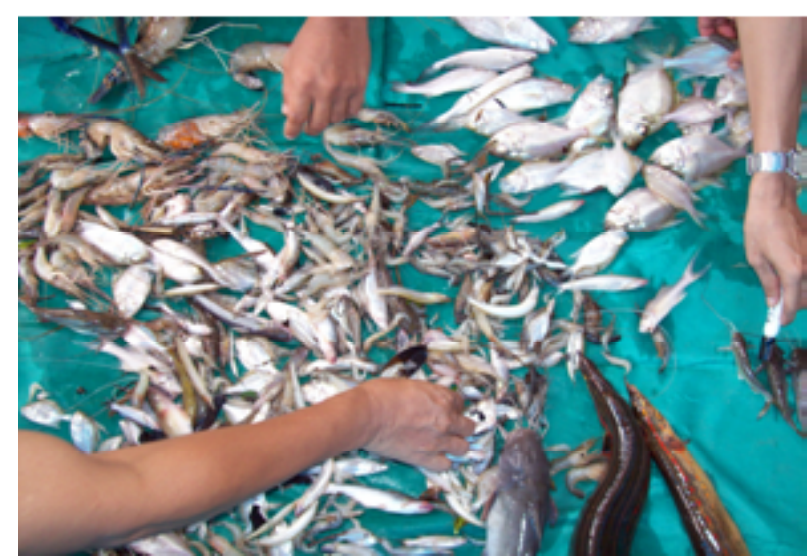

Gambar 5. Ikan blumbungan (Otolithus rubber).

Nilai indeks keragaman jenis ikan hasil tangkapan blad di perairan estuaria Sungai Upang $(2,87)$, Sungai Musi $(1,95)$, Sungai Banyuasin $(1,67)$, dan Sungai Sembilang $(2,17)$. Indeks keragaman jenis ikan $\left(\mathrm{H}^{\prime}\right)$ di 4 lokasi penelitian mempunyai nilai $<3$ dan $>1$, keragaman jenis tingkat sedang (Newman, 1995).

Hasil tangkapan utama yang diharapkan nelayan adalah udang karena harga jual yang lebih tinggi dibanding ikan. Komposisi hasil tangkapan ikan, dan udang berdasarkan pada persentase bobot masingmasing lokasi pengamatan Sungai Upang 62,91:37,09\%; Sungai Musi 54,11:45,89\%; Sungai Banyuasin 88,73:11,27\%; dan Sungai Sembilang $86,61: 13,39 \%$. Biaya investasi dan opersional alat relatif kecil (alat tangkap pasif) dan hasil tangkapan (udang) bernilai ekonomi tinggi sehingga dapat memberikan pendapatan nelayan relatif lebih tinggi dibanding jenis alat tangkap yang lain.

Hasil tangkapan per unit upaya (catch per unit of effort) tertinggi di Sungai Upang $8,75 \mathrm{~kg}$, Sungai Sembilang $5,80 \mathrm{~kg}$, Sungai Musi $4,95 \mathrm{~kg}$, dan Sungai Banyuasin 2,30 kg per $100 \mathrm{~m}$ jaring blad per trip operasi. Sesuai dengan ukuran mesh size jaring blad $(4 \mathrm{~mm})$, alat tangkap blad tergolong alat tangkap yang tidak selektif karena ukuran ikan dan udang yang tertangkap sangat bervariasi.

\section{KESIMPULAN}

1. Alat tangkap blad dibuat dari bahan jaring mesh size $4 \mathrm{~mm}$ ukuran panjang 100 sampai dengan $400 \mathrm{~m}$, lebar 2,0 sampai dengan $3,0 \mathrm{~m}$. Alat tangkap pasif, dipasang memanjang garis pantai pinggiran sungai, menjebak ikan yang bermigrasi secara lateral saat air pasang. Dapat dioperasikan 14 sampai dengan 18 hari per bulan, sepanjang tahun dominan di musim kemarau.

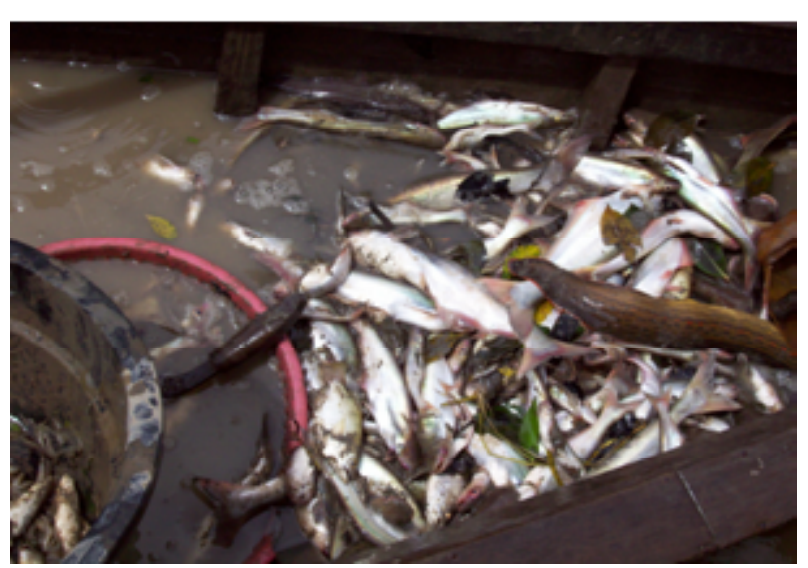

Gambar 6. Ikan blumbungan (Otolithus rubber).

2. Komposisi jenis hasil tangkapan 61 jenis terdiri atas 54 jenis ikan dan 7 jenis udang. Komposisi bobot ikan $73,0 \%$ dan udang $27,0 \%$. Nilai indeks keragaman jenis 1,95 sampai dengan 2,87 (tingkat sedang). Hasil tangkapan per unit upaya (catch per unit of effort) 2,31 sampai dengan $8,75 \mathrm{~kg}$ per $100 \mathrm{~m}$ jaring per jam operasi.

\section{PERSANTUNAN}

Kegiatan dari hasil riset kajian perikanan di estuari yang bermuara di Selat Bangka, Sumatera Selatan, T.A. 2007, di Balai Riset Perikanan Perairan UmumMariana, Palembang.

\section{DAFTAR PUSTAKA}

Agueron, M. \& B. A. Lockwood. 1986. Resources management is people management. $P: 345-347$. In J. L. Maclean, L. B. Dixon, \& L. V. Hosilos (Eds). The Fish Asian Fisheries Forum, Asia Fisheries Society, Manila.

Bengen, D. G. 2000. Pusat kajian sumber daya pesisir dan lautan. Fakultas Perikanan dan Ilmu Kelautan. Institut Pertanian Bogor. Bogor.

Gaffar, A. K. 1999. Ketersediaan teknologi dan program penelitian perikanan air tawar perairan umum. Loka Penelitian Perikanan Air Tawar. 1999.

Kottelat, M., A. J Whitten, S. N Kartikasari, \& S. Wirjoatmodjo. 1993. Freshwater fishes of western Indonesia and Sulawesi (ikan air tawar Indonesia bagian barat dan Sulawesi). Periplus EditionProyek EMDI. Jakarta.

Newman, M. C. 1995. Quantitative methods in aquatic ecotoxiology. Savannah River Ecology Laboratory The University of Georgia Aiken. South Carolina. 
Wardoyo, S. A. 2001. Laporan survei perikanan di kawasan CTN Sembilang, Juli 2001. Proyek Konservasi Lahan Basah Pesisir BerbakSembilang GEF MSP (TF-0240011). Wetland International-Asia Pasific Indonesia Program.
Weber, M. \& De Beufort. 1916. The fishes of the IndoAustralian Arcohipelago. E. Journal Brill Itd. Leiden. Jilid 1 sampai dengan 12. 